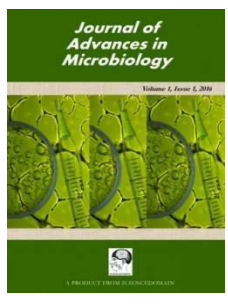

\title{
Antagonistic Compounds Producing Plant Growth Promoting Rhizobacteria: A Tool for Management of Plant Disease
}

\author{
Himanshu Singh ${ }^{1}$, Vishakha Jaiswal ${ }^{2}$, Siddhi Singh ${ }^{2}$, S. P. Tiwari ${ }^{1}$ \\ Bharti Singh ${ }^{3}$ and Deepmala Katiyar ${ }^{4^{*}}$ \\ ${ }^{1}$ Department of Microbiology, Veer Bahadur Singh Purvanchal University, Jaunpur, India. \\ ${ }^{2}$ Department of Biochemistry, Veer Bahadur Singh Purvanchal University, Jaunpur, India. \\ ${ }^{3}$ Vitae Gen Biotech-Educational and Research Institute, Varanasi, India. \\ ${ }^{4}$ Department of Plant Physiology, Institute of Agricultural Sciences, Banaras Hindu University, \\ Varanasi, India.
}

\section{Authors' contributions}

This work was carried out in collaboration between all authors. Authors HS, VJ and SS wrote the first draft of the manuscript. Authors SPT and BS managed the literature searches. Author DK had proposed the topic for review and revised the manuscript. All authors read and approved the final

manuscript.

Article Information

DOI: $10.9734 / \mathrm{JAMB} / 2017 / 33368$

(1) Niranjala Perera, Department of Food Science \& Technology, Wayamba University of Sri Lanka, Sri Lanka.

Reviewers:

(1) Selma Gomes Ferreira Leite, Universidade Federal do Rio de Janeiro, Brasil.

(2) Soraya Gabriela Kiriachek, Universidad Nacional de La Pampa, Argentina. (3) Bernard R. Glick, University of Waterloo, Canada.

(4) Ilham Zahir, Sultan Moulay Slimane University, Beni Mellal, Morocco.

(5) Armando Zepeda Bastida, Instituto de Ciencias Agropecuarias, Universidad Autónoma del Estado de Hidalgo, Mexico. Complete Peer review History: http://www.sciencedomain.org/review-history/19475

Review Article

Received 11 ${ }^{\text {th }}$ April 2017

Accepted 6 $6^{\text {th }}$ June 2017

Published $10^{\text {th }}$ June 2017

\section{ABSTRACT}

Agriculture is facing struggle to meet the various confront of reducing plant diseases for an increasing world population food security. Great quantities of synthetic fertilizers and pesticides are required for high productivity which can damage ecosystem structures and functions, including the soil microbial community which plays an important role in agriculture sustainability. Soil is an excellent niche of growth of much plant growth promoting rhizobacteria. PGPR are naturally occurring soil bacteria that aggressively colonize in plant roots and play a vital role in crop 
protection, growth promotion and in the improvement of soil health. Scientific researchers involve multidisciplinary approaches to understand adaptation of PGPR, effects on plant physiology and growth induced systemic resistance, biocontrol of plant pathogens and biofertilization. The primary mechanism of biocontrol by PGPR involves the production of antibiotics such as carboxylic acid, 2,4-diacetyl phloroglucinoloomycin,pyoluteorin,pyrrolnitrin,kanosamine,zwittemycin-A and pantocin. A cascade of endogenous signals such as sensor kinases, $\mathrm{N}$-acyl homoserine lactones and sigma factors regulates the synthesis of antibiotics. Some of these antibiotics have broad spectrum against many plant pathogens like fungi, viruses and bacteria, affecting crop plants. These antibiotics also serve as determinants in triggering induced systemic resistance (ISR) in the plant system.

Keywords: Antibiotic; plant growth promoting rhizobacteria; indirect plant growth promotion; rhizosphere.

\section{INTRODUCTION}

Plant growth promoting rhizobacteria (PGPR) are naturally occurring heterogenous group of soil bacteria that are found in rhizosphere, and actively colonized in plant root and increase plant growth directly and indirectly [1]. The term PGPRs was coined by Joe Kloepper in late 1970 and was defined by Kloepper and Schroth [2]. PGPRs are known to influence plant growth by various mechanisms (Fig. 1).

PGPR is being used as biofertilizer and bioenhancer for different crop plant as an alternative source of chemical fertilizer. In present scenario, 72 bacterial isolates have been reported as efficient PGPR which belong to Azotobacter, Pseudomonas, Mesorhizobium, Bacillus and Serratia [3,4,5]. After various studies, it was found that $P$. fluorescens, annual plant, co-inoculate with more than one biological control agent. Biocontrol is the phenomenon in which organisms (or their metabolites) are used as a natural fighter or inhibitor of a pest or Phytopathogen [6] to reduce or remove its bad effect on the plant physiology or its product. PGPR have been reported to be present in high populations in the rhizosphere and as endophytes of many crops. They include species of Enterobacter, Bacillus, Klebsiella, Herbaspirillum, Burkholderia, Azospirillum, and Gluconacetobacter $[7,8]$. The presence of biocontrol activity of organism or agents in the environment is the important reason behind that many agricultural products are not completely destroyed by pathogens and diseases because those organisms have ability to antagonizing with pathogen by the reduction of its unnecessary or harmful effects [9]. According to various studies, it was shown that antibiotic production elucidates mechanism of action on antagonistic microorganism [10].

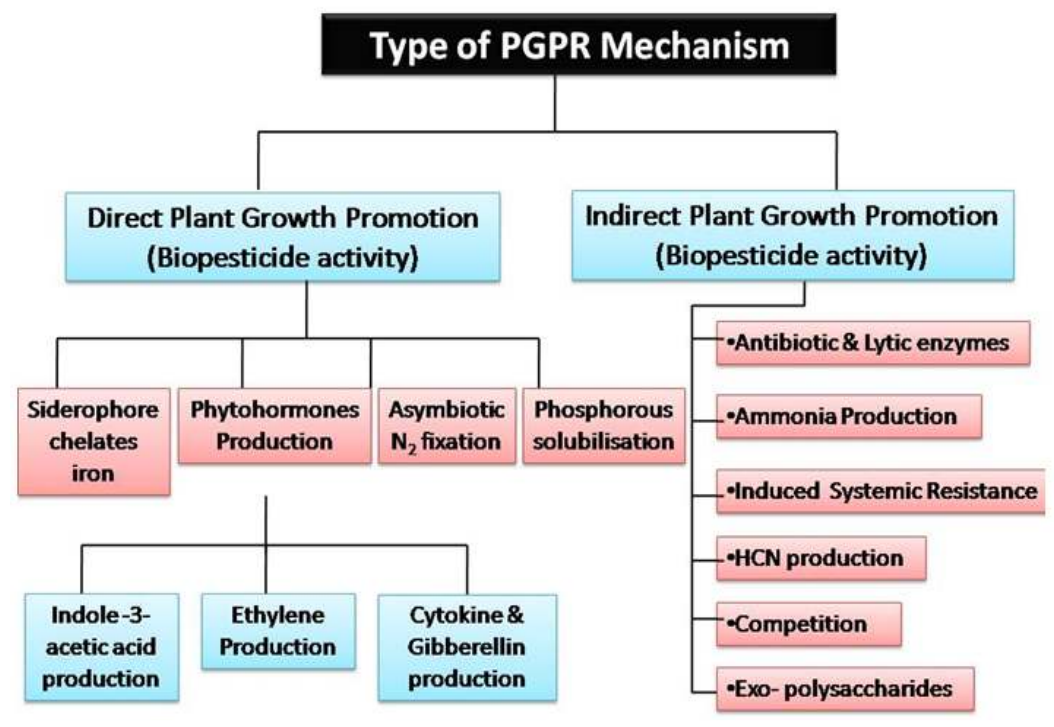

Fig. 1. Type of plant growth promoting rhizobacteria mechanism 


\section{MECHANISM OF ACTION OF PGPR (DIRECT AND INDIRECT)}

The mechanism by which PGPR promote plant growth are not fully understood [I] The ability to produce or change the concentration of plant growth regulators like indole-acetic acid, gibberellic acid, cytokinins and lowering plant level [11,5] [II] Asymbiotic $\mathrm{N}_{2}$ fixation [12]. [III] Antagonism against phytopathogenic Microorganism by production of antibiotics [13] and cyanide [14]. [IV] Solubilization of mineral phosphate (biological phosphate mineralization) and other nutrient that release complexing or mineral dissolving compound e.g. organic acid anions, protons, hydroxyl ion and carbon di hydroxides [15,16]. [V] Azospirillum, Pseudomonas and Azotobacter strains could affect seed germination and seedling growth. In natural ecosystem, beneficial plant associated bacteria play an important role in supporting and increasing plant health and growth [17]. Some soil borne microorganisms can enter roots and stabilized subpopulation ranging from $10^{5}$ to $10^{7}$ CFU $\mathrm{g}^{-1} \mathrm{FW}$. The good result obtained in vitro cannot always be dependably reproduced under field conditions $[18,19,20]$.

\section{ANTAGONISTIC COMPOUNDS, MODE OF ACTION AND PPGR TARGETS}

Antibiotics are heterogeneous group and are low molecular weight of organic compound that are harmful to the growth and metabolic activity of microorganisms [21]. Most of the antibiotics are peptides in nature and effective or active against fungal growth like as cyanide lipopeptide, phosphoro-oligopeptide and phosphorodipeptide [22]. Antagonistics produced by bacteria include volatile compounds (hydrogen cyanide, aldehydes, alcohols, ketones, and sulfides) and nonvolatile antibiotics: polyketides (diacetylphloroglucinol; DAPG and mupirocin), heterocyclic nitrogenous compounds (phenazine derivatives: pyocyanin, phenazine-1-carboxylic acid; phenazine-1- carboxylate (PCA), and phenazine-1-carboxamide (PCN) and hydroxyphenazines) [23] and phenylpyrrole antibiotic (pyrrolnitrin) [24] (Fig. 2). The most widely studied group of rhizospheric bacteria described as being implicated in biocontrol was phenazine fluorescent Pseudomonads [25]. Numerous types of antibiotics have been isolated from fungal and bacterial strains and this diversity includes mechanisms of action that inhibit synthesis of pathogen cell walls, influence membrane structures of cells and inhibit the formation of initiation complexes on the small subunit of the ribosome [26]. Pyrrolnitrin, the antibiotic produced by the $P$. fluorescensBL915 strain, is able to prevent the damage of Rhizoctonia solani during damping-off of cotton plants. In soils, antibiotic 2, 4 diacetylphloroglucinol (2, 4- DAPG) producing Pseudomonas sp. was reported for biocontrol of disease in wheat caused by the fungus Gaeumanomyces graminis var. Tritici Bacterization of wheat seeds with $P$. fluorescens strains producing the antibiotic phenazine-1carboxylic acid (PCA) resulted in significant suppression of take-all in about $60 \%$ of field trials [27].

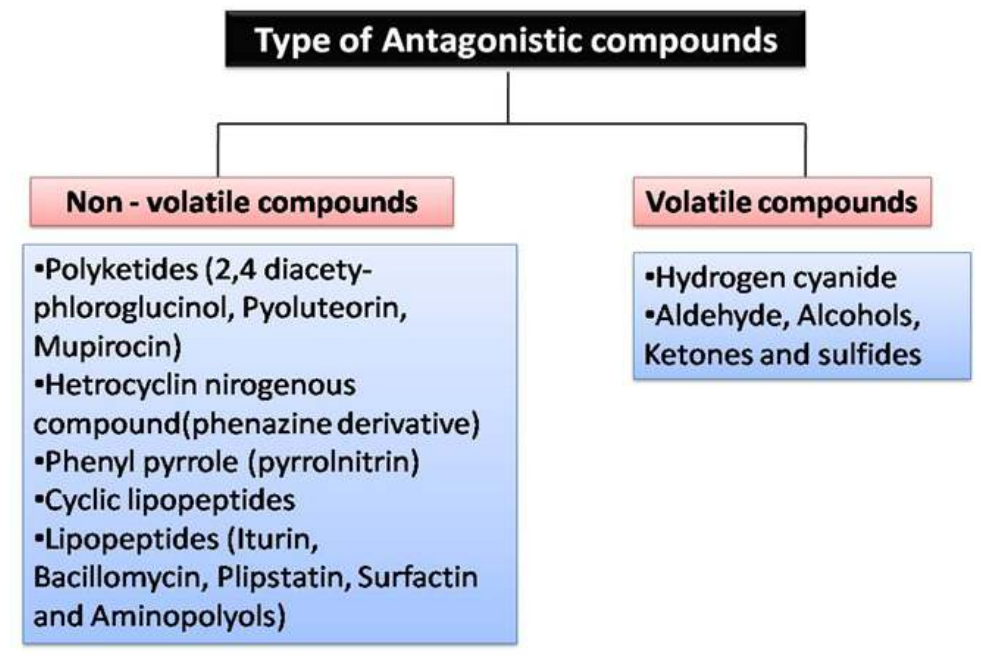

Fig. 2. Major two group of antagonistic compounds for the suppression of plant pathogens 


\section{TYPE OF COMPOUNDS}

Synthesis of natural antibiotics by plant growth promoting rhizobacteria (PGPR) include 2,4 diacetalphloroglucinol, phenzine-1-carboxylic acid, phenazine-1-carboxamide, pyoluteorin, pyrolnitrin, oomycin, antitumor antibiotics FR901463, butyrolactones, kanosamin, zwittermycin A, aerogine, rhamnolipids, cepacimide A, pseudomonic acid, azomycin A, cepafungins and antiviral antibiotics karalicin. All these antibiotics have antiviral, antimicrobial, antihelminthic, phytotoxic, antioxidant and cytotoxic effect and they are also helpful in plant growth [28]. Each of the antibiotics have different way of work based on different action some of which attack the cellular membrane and some other have inhibitory effect on ribosome and other cellular organism [28] that's why some of them are susceptible to some antibiotics but not other depending on the specific form of cellular organelles. Six classes of antagonistic compounds such as phenazines and phloroglucinol, pyoluteorin, pyrrolnitrin, cyclic lipopeptide (all of which are diffusible in nature) and $\mathrm{HCN}$ are much more related to the biocontrol of root disease [29]. Recently discovered lipopeptide, biosurfactants produced by Pseudomonas and Bacillus species have been apply in bio control because of their potential positive effect of competitive interaction with organism which include bacteria, fungi, oomycetes, protozoa, nematodes, and plants $[30,31]$.

Zwittermycin, Kanosamine are Novel class of antibiotics produce by $B$. cereus UV85. In antibiotics synthesis, $B$. cereus modifies the ionic composition of medium in which it grows and raises the $\mathrm{pH}$, sequesters $\mathrm{Ca}^{++}$, and excretes ammonia. This combination is highly toxic to zoospores of oomycete pathogens, causing rapid swelling of the expulsion vacuole, followed by zoospore lysis [32].

Sigma factor are important for regulation of antibiotic production in florescence Pseudomonad; housekeeping factor sigma [70] and the stress-related sigmas have important role in production of antibiotic metabolites in disease suppression [29].

Table 1 lists the heterogeneous group of organic compound that prevent the development of pathogens and its metabolic activity and very helpful in plant growth and development.

\section{POSSIBLE MECHANISMS THAT INCREASE RESISTANCE}

\subsection{Antibiotic}

Natural Antibiotic synthesizer must contain some antibiotic resistance mechanism to stop them committing suicide through formation of their own toxins. Environment of soil is very important for research into the mechanism of antibiotic resistance, including possible mechanism which is not yet seen in clinical microbiology [54].On a given population when antibiotics are a constant pressure then antibiotic resistance occur; those organisms with natural resistance can survive easily and also reproduce easily whereas those organisms which do not have resistance factor are die [55]. Once a resistance factor has developed, it can be rapidly spread within a population where DNA is transfer from one bacterium to another bacterium [56]. Transfer of DNA containing antibiotic genes can do by three processes (1) Transformation (2) Transfection (3) Conjugation.

Production of natural antibiotic by bacteria mainly Pseudomonads, seems to be closely regulated by two- component system involving an environmental sensor (a membrane protein) and cytoplasmic response factor [57]. In biocontrol bacteria, most known cases involve the AHL ( $\mathrm{N}$-acetyl homoserine lactone) control of phenazines antibiotics synthesized by rhizospheric Pseudomonads. Recent findings demonstrate that phenazines are not only group of biocontrol related antibiotics, but its synthesis or production is regulated through QS System (Quorum Sensing System). Bacillus polymyxa strain Pw-2R and Pseudomonas fluorescence strain Sw5-RN a spontaneous antibioticresistant derivatives of the naturally occurring parental strains $B$. polymyxa $\mathrm{Pw}-2$ and $P$. fluorescence Sw5 respectively [58]. Expression of several phenotypic characteristics in bacteria e.g. bioluminescence, biofilm formation, motility, production of virulence factors, exoenzymes and antibiotics is often a cell-density-dependent phenomenon mediated by cell-to-cell communication in a process known as quorum sensing (QS). The main QS system, known as Lux IR, operates to control the response, mainly via production of $\mathrm{N}$-acylated homoserine lactone (AHL) signaling [59]. Various PGPR, which are able to protect plant from fungal and bacterial disease, have been found to produce $\mathrm{AHL}$ and other QS signals [60]. Antibiotics are major determinants of antagonism against fungi by 
various PGPR, among the fluorocent Pseudomonads, many strains produce one or more potent metabolites with antifungal activity, the best-characterized are simple compounds such as phenazines, 2-4 diacetylphloroglucinol, 3-chloro-4- (20 - nitrochlorophenyl) pyrrole (pyrrolnitrin) and pyoluteorin [61]. However, only a few examples of the role of QS system in the regulation of these secondary metabolites production have been described. Most known cases involve the $\mathrm{AHL}$ control of phenazines antibiotics $[60,39]$. Four different LuxRI/AHL QS systems have been described in Serratia [61, 62]. These systems control population surface migration, biofilm development and production of the bio-surfactant serrawettin, the antibiotics carbapenem and prodiogosin, chitinases, proteases and other exoenzymes [63,64,65, $66,67]$. These lipopeptides displayed dosedependent antifungal activity against a broad spectrum of phytopathogens and were weakly antagonistic to Staphylococcus aureus. Lipopeptides produced by this strain were isolated, purified by HPLC system, elucidated by NMR spectroscopy and MS spectrometry techniques, and the antimicrobial activities were evaluated with paper disc-agar diffusion assay The cytotoxic activities were based on 3(4,5 dimethylthiazol-2-yl)-2,5-diphenyltetrazolium bromide assay. On the other hand, bacteria can produce a wide variety of compounds with antimicrobial activity used as defense systems. These include broad-spectrum antibiotics, lactic acid produced by lactobacilli, lytic agents such as lysozymes, numerous types of exotoxins and bacteriocins, which also have a bactericidal mode of action [68]. Siderophores, bacteriocins and antibiotics are three of the most effective and well known mechanisms that an antagonist can employ to minimize or prevent phytopathogenic proliferation.

\subsection{Bacteriocin as another Defense Molecule}

Bacteriocins are bacterially product synthesized peptides (protein) that are either may be bacteriostatic or may be bacteriocidal against strains related to the synthesizer strain [69]. Various types of bacteriocinsare identified (Table 2). Although determining the sequence of amino acid of bacteriocins can often be difficult, due to presence of modified amino acid. In microbial defense system other defense molecule are used as bacteriocins. Researcher reported that the nature of bacteriocins differ from traditional antibiotics in one critical manner
[68]. They commonly have a relatively narrow killing spectrum and are only harmful or toxic for closely related to the bacteriocins producing strain. Near about all the bacterium may make at least one bacteriocin and many types of bacteriocins isolated from Gram- negative bacteria appear to have been created by recombination between existing bacteriocins [70]. The colicin proteins are very representative bacteriocin produced by some strain of $E$. coli that are lethal for related strain $E$. coli is a Gram negative bacterium and the colicin's name derived from E. coli; therefore, other bacteriocins have been thusdefined. Interestingly bacteriocins from Bacillus spp. are increasingly becoming much more important because of their sometimes broader spectra of inhibition (As compared with most lactic bacterial bacteriocins).

\subsection{Bacteriocin Classes}

Several classes of bacteriocins have been described based on their size, post-translational modification, production and heat liability $[71,72]$ as follows:

Class I- Includes the lantibiotics, bacteriocins that possess the characteristic lanthionine moiety and are after produced by lactic acid bacteria [73]

Class II- Exclude the lantibiotics and contain heat stable bacteriocins. This class is also subdivided into section $\mathrm{a}, \mathrm{b}$ and c members.

Class/l a- Is conserved sequence homology of at least YGNGVXC.

Class/l b-Bacteriocins need two bacteriocins for antibiotics activity.

Class/l c-Comprises all other class II bacteriocins [71].

Class III- Contain larger (730 KDa) heat labile bacteriocins

Class IV- Contain bacteriocins that are modified with either Lipid or Carbohydrate components [72].

The recently discovered PGPR is Bacillus thuringiensis NEB17 that help to enhance the growth of soybean [74]. This strain also synthesizes a bacteriocin, thuricin 17 , which is a low molecular weight peptide (3162 KDa). It presents an inhibitory or a harmful effect against Bacillus strains [75]. Thuricin 17 is stable across a $\mathrm{pH}$ range of 1.0 to 9.25 , highly heat resistant and is inactivated by treatment with proteolytic enzymes [75]. 
Table 1. Plant growth promoting rhizobacteria and their mode of action

\begin{tabular}{|c|c|c|c|c|c|}
\hline S. N. & Antibiotics & Source & Target organism & Mode of action & Reference \\
\hline 1 & Bacillomycin & Bacillus & Aspergillus flavus & - & [33] \\
\hline 2 & $\begin{array}{l}\text { Kanosamine } \\
\text { (Aminoglycoside) }\end{array}$ & Bacillus cereus & Phytophthora medicaginis & $\begin{array}{l}\text { Contribute to biocontrol of alfalfa } \\
\text { dumping off }\end{array}$ & {$[34,35]$} \\
\hline 3 & Zwittermicin A & B. cereus UW85 strain & Phytophthora & Suppresses Oomycete pathogens & {$[34,38]$} \\
\hline 4 & $\begin{array}{l}\text { Pyrrolnitrine } \\
\text { (From this fungicide } \\
\text { fluidioxonil can be derived) }\end{array}$ & $\begin{array}{l}\text { Pseudomonas } \\
\text { fluoroscens BL915 strain } \\
\text { Pseudomonas sp. }\end{array}$ & R. solani & $\begin{array}{l}\text { Able to prevent the damage of } R \text {. solani } \\
\text { during dumping of cotton plant and this } \\
\text { fungicide is used for seed treatment } \\
\text { and foliar spray or soil drench }\end{array}$ & {$[36,37]$} \\
\hline 5 & $\begin{array}{l}\text { 2,4 diacetylfluoroglucinol } \\
\text { (DAPG) }\end{array}$ & Pseudomonads & $\begin{array}{l}\text { Phythium species and particularly } \\
\text { zoospores of oomycete }\end{array}$ & $\begin{array}{l}\text { Membrane damage to phythium } \\
\text { species and is particularly inhibitory to } \\
\text { zoospore of oomycete }\end{array}$ & {$[37,13]$} \\
\hline 6 & Phenazine & Pseudomonads & $\begin{array}{l}\text { F. oxysporum and } \\
\text { Gaeumahnomyces graminis }\end{array}$ & $\begin{array}{l}\text { Posses redox activity and can suppress } \\
\text { pathogen of plant }\end{array}$ & [39] \\
\hline 7 & Phenazine- 1-carboxamide & $\begin{array}{l}\text { P. chlororaphis PCL } 1391 \\
\text { strain }\end{array}$ & - & $\begin{array}{l}\text { Which is able to release soluble iron } \\
\text { from insoluble ferric oxide at neutral } \\
\mathrm{pH} \text {, raising the possibility that } \\
\text { phenazenes might contribute to iron } \\
\text { mobilization in soil }\end{array}$ & {$[40,41]$} \\
\hline 8 & $\begin{array}{l}\text { Polymyxin, Circulin and } \\
\text { Calistin }\end{array}$ & Bacillus sp. & $\begin{array}{l}\text { Gram positive Gram negative } \\
\text { bacteria and as well as many } \\
\text { pathogenic Fungi }\end{array}$ & - & [26] \\
\hline 9 & $\begin{array}{l}\text { Streptomycin and } \\
\text { Oxytetracyclin }\end{array}$ & Pseudomonas sp. & Erwinia amylovora & $\begin{array}{l}\text { Control of fire blight (some pathogenic } \\
\text { strain resistant to the antibiotic appears } \\
\text { in several growing region) by } \\
\text { Streptomycin And a disease of pear } \\
\text { apple coused by E. amylovora } \\
\text { (oxytetracyclin is less effective than } \\
\text { Streptomycin for suppression on } \\
\text { antibiotic sensitive population of E. } \\
\text { amylovora) }\end{array}$ & [42] \\
\hline 10 & Iturin & B. subtilis & $\begin{array}{l}\text { Phythiumultimum, } R \text {. soloni, } \\
\text { F. oxysporum, S. sclerotiorum and } \\
\text { M. phaseolin }\end{array}$ & - & [43] \\
\hline
\end{tabular}


Singh et al.; JAMB, 3(4): 1-12, 2017; Article no.JAMB.33368

\begin{tabular}{|c|c|c|c|c|c|}
\hline S. $\mathbf{N}$. & Antibiotics & Source & Target organism & Mode of action & Reference \\
\hline 11 & Iturin A and Surfactin & Bacillus sp. & R. soloni & - & [44] \\
\hline 12 & Phenazin-1-carboxylic acid & Pseudomonas sp. & Antifungal & - & [45] \\
\hline 15 & Pyrrolnitrin & Pseudomonas sp. & Antifungal & - & [37] \\
\hline 14 & Pyuteorin & Pseudomonas sp. & Antifungal & - & [46] \\
\hline 15 & Oomycin & Pseudomonas sp. & Antifungal & - & [47] \\
\hline 16 & Copaciamide A & Pseudomonas sp. & Antifungal & - & [48] \\
\hline 17 & Ecomycins & Pseudomonas sp. & Antifungal & - & [49] \\
\hline 18 & DDR & Pseudomonas sp. & Antifungal & - & [50] \\
\hline 19 & Viscosinamide & Pseudomonas sp. & Antifungal & - & [51] \\
\hline 20 & Butyrolactones & Pseudomonas sp. & Antifungal & - & [52] \\
\hline 21 & Sulphonamide & Pseudomonas sp. & Antifungal & - & [47] \\
\hline 22 & Pyocyanin & Pseudomonas sp. & Antifungal & - & {$[52,53]$} \\
\hline
\end{tabular}

Table 2. Bacteriocins of plant growth promoting rhizobacteria and their source

\begin{tabular}{|c|c|c|c|}
\hline SI. No. & Bacteriocins & Source & References \\
\hline 1 & $\begin{array}{l}\text { Thuricin 439A and Thuricin 439B (share the partial N- } \\
\text { terminal sequence WVAXVGAXGTAALASGGVV) }\end{array}$ & Bacillus thuringiensis 439 & [76] \\
\hline 2 & Cerein7( N-terminal sequence-GWGDVL) & Bacillus cereus $\mathrm{Bc7}$ & [77] \\
\hline 3 & Bacthuricin F4 (N-terminal sequence- DWTXWSXL) & B. thuringiensis spp. Kurstaki strain BUPM & [78] \\
\hline 4 & Pyocins & P. pyogenes strain & [79] \\
\hline 5 & Cloacins & Enterobacter cloacae & [79] \\
\hline 6 & Marcescins & Serratia marcescens & [79] \\
\hline 7 & Megacins & B. megaterium & [79] \\
\hline 8 & Thuricin 17 & B. thuringiensis NEB17 & [75] \\
\hline
\end{tabular}




\section{CONCLUSION}

Plant pathologists are facing major challenges for the management of soil-borne plant pathogens. Excessive use of pesticides against plant pathogens has resulted in environmental pollution and resistance among pathogens. Subsequently, identification of suppressive soils to various soil borne plant pathogens such as Gaeumanomyces graminis, Var. tritici. [80]. This present review revealed that environment is confer with an intensify biodiversity of PGPR. The prevailing bacterial microfloras in the PGPR community include Pseudomonas spp., Enterobacter spp. and Bacillus spp. Among the wide genetic biodiversity of prokaryotes, plant growth promoting rhizobacteria (PGPR) play a vital role in the management of plant diseases to increase crop productivity via various mechanisms [2]. Considerable progress has been made over the past two decades to elucidate the mechanisms by which fluorescent Pseudomonads suppress diseases. The primary mechanism of biocontrol by fluorescence Pseudomonads involves production of antibiotics such as 2, 4-diacetylphloroglucinol, pyoluteorin, pyrrolnitrin, phenazine-1-carboxyclic acid, 2- hydroxyphenazines and phenazine-1carboxamide. In addition to direct antipathogenic action, antibiotics also serve as determinants in triggering induced systemic resistance (ISR) in the plant system and contribute to disease suppression by conferring a competitive advantage to biocontrol agents. Synergism between antibiotics and ISR may further increase host resistance to plant pathogens. Though several modes of action are responsible for the suppression of plant pathogens, this review focused on new insights in biocontrol of plant pathogens by PGPR through antibiotics.

\section{COMPETING INTERESTS}

Authors have declared that no competing interests exist.

\section{REFERENCES}

1. Cattelan AJ, Har Tel PG, Fuhrmann JJ. Screening for plant growth-promoting rhizobacteria to promote early soybean growth. Soil Sci. Society Am. J. 1999; 63:1670-1680.

2. Katiyar D, Hemantaranjan A, Singh B. Crop fungus pathogen management by plant growth promoting rhizobacteria. In
Edited Rao RK. Climate Change and its Implications on Crop Prod and Food Sec. 2017;280-284.

3. Kloepper JW, Lifshitz R, Zablotwicz RM. Free-living bacterial inocula for enhancing crop. Productivity Trend Biotechnol. 1989; 7:39-43.

4. Okon Y, Labandera-Gonzalez CA. Agronomic applications of Azospirillum. In: Ryder, M.H., Stephens, P.M., BOWen, G.D. (Eds.), Improving plant productivity with rhizosphere bacteria. Common wealth Scientific and Industrial Research Organization, Adelaide, Australia. 1994; 274-278.

5. Glick BR. The enhancement of plant growth by free living bacteria. Can. J. Microbiol. 1995;41:109-114.

6. McSpadden BB, Fravel DR. Biological control of plant pathogens: Research, commercialization, and application in the USA. Department of Plant Pathology, The Ohio State University-OARDC, Wooster43; 2002.

7. De Freitas JR, Banerjee MR, Germida JJ. Phosphate solubilizing rhizobacteria enhance thegrowth and yield but not phosphorus uptake of canola (Brassica napus L.). Biol. Fertil. Soil. 1997;24:358364.

8. Katiyar D, Hemantaranjan A, Singh B. Plant growth promoting rhizobacteria-an efficient tool for agriculture promotion. Advances in Plants and Agriculture Research. 2016;4(6):00163.

9. Anaya AL. Allelopathic organisms and molecules: Promising bioregulators for the control of plant diseases, weeds, and other pests. In Mukerji, K. G. Editor. Allelochemical biological control of plant pathogens and diseases. Netherlands Springer. 2006;31-78.

10. Benbow JM, Sugar D. Fruit surface colonization and biological control of postharvest diseases of pear by preharvest yeast applications. Plant Diseases. 1999;83:839-44.

11. Arshad M, Frankenberger JWT. Microbial production of plant growth regulators. In: Blaine F., Metting Jr. (Eds.), Soil Microbiol. Eco. Marcel and Dekker, Inc., New York. 1993;307-347.

12. Boddey RM, Dobereiner J. Nitrogen fixation associated with grasses and cereals: Recent progress and perspectives for the future. Fert. Res. 1995;42:241250. 
13. Shanahan $P O$, Sullivan DJ, Simpson $P$, Glennon JD, O'Gara F. Isolation of 2,4diacetylphlorogucinol from a fluoroscent pseudomonad and investigation of physiological parameters influencing its production. Appl. Environ. Microbiol. 1992; 58:353-358.

14. Flaishman MA, Eyal ZA, Zilberstein A, Voisard C, Hass D. Suppression of Septoria tritci blotch and leaf rust of wheat by recombinant cyanide producing strains of Pseudomonas putida. Mol. Plant Microbe Interact. 1996;9:642-645.

15. De Freitas JR, Banerjee MR, Germida JJ. Phosphate-solubilizing rhizobacteria enhance the growth and yield but not phosphorus uptake of canola (Brassica napus L.). Biol. Fertil. Soils. 1997;24:358364.

16. Gaur AC. Physiological functions of phosphate solubilizing micro-organisms. In: Gaur A.C. (Ed.), Phosphate Solubilizing Micro-organisms as Biofertilizers. Omega Scientific Publishers, New Delhi. 1990;1672.

17. Sessitsch A, Puschenreiter M. Endophytes and rhizosphere bacteria of plants growing in heavy metal contaminated soil. In: Dion P., Nautiyal C.S., editors. Microbiology of Extreme Soils. Springer; Berlin Heidelberg; 2008.

18. Jarvis B, Lach VH, Wood JM. Evaluation of the spiral plate maker for the enumeration of microorganisms in foods. J. Appl. Bacteriol. 1977;43:149-157.

19. Chanway CP, Holl FB. First year yield performanceof spruce seedlings inoculated with plant growth promoting rhizobacteria. Can. J. Microbiol. 1993;39:1084-1088.

20. Zehnder GW, Yao C, Murphy JF, Sikora ER, Kloepper JW, Schuster DJ, Polston JE. Microbe-induced resistance against pathogens and herbivores: Evidence of effectiveness in agriculture. In: Induced plant defenses against pathogens and herbivores, biochemistry, ecology, and agriculture. A. A. Agrawal, S. Tuzun, and E. Bent, eds. American Phytopath. Society Press, St. Paul, MN. 1999;335-355.

21. Duffy B. Pathogen self-defense: Mechanisms to counteract microbial antagonism. Annu Rev Phytopathol. 2003; 41:501-38.

22. Ongena $M$, Jacques $P$. Bacillus lipopeptides: Versatile weapons for plant disease biocontrol. Trends Microbiol. 2008; 16:115-125.
23. De Souza JT, Arnould C, Deulvot C, Lemanceau P, Gianinazzi-Pearson V, Raaijmakers JM. Effect of 2,4diacetylphloroglucinol on Pythium: Cellular responses and variation in sensitivity among propagules and species. Phytopathology. 2003;93:966-975.

24. Ahmad F, Ahmad I, Khan MS. Screening of free-living rhizospheric bacteria for their multiple plant growth promoting activities. Microbiol. Res. 2008;63(2):173-81.

25. Weller DM, Cook RJ. Suppression of take all of wheat by seed treatment with fluorescent pseudomonad. Phytopathol. 1983;73: 463-469.

26. Maksimov IV, Abizgil'dina RR, Pusenkova LI. Plant growth promoting rhizobacteria as alternative to chemical crop protectors from pathogens (Review). Appl Biochem Microbiol. 2011;47:333-345.

27. Hill DS, Stein JI, Torkewitz NR, Morse AM, Howell CR, Pachlatko JP, Becker JO, Ligon JM. Cloning of genes involved in the synthesis of pyrrolnitrin from Pseudomnas fluorescens and role of pyrrolnitrin synthesis in biological control of plant disease. Appl. Environ. Microbiol. 1994; 60:78-85.

28. Reid TC, Hausbeck MK, Kizilkaya K. Use of fungicides and biological controls in the suppression of Fusarium crown and root of asparagus under greenhouse and growth chamber conditions. Plant Diseases. 2002; 86:493-98.

29. Schnider U, Keel C, Troxler J, Defogo G, Haas D. Amplification of the housekeeping sigma factor in Pseudomonas. Fluorenscense (CHAO enhances antibiotic production and improves biocontrol abilities. J Bacteriol. 1995;177:5387-5392.

30. De Bruijn I, De Kock MJD, Yang M, De Waard P, Van Beek TA, Raaijmakers JM. Genome-based discovery, structure prediction and functional analysis of cyclic lipopeptide antibiotics in Pseudomonas species. Mol Microbiol. 2007;63:417-42.

31. Raaijmakers JM, De Bruijn I, De Kock MJ. Cycliclipopeptide production by plantassociated Pseudomonas spp.: Diversity, activity, biosynthesis, and regulation. Mol. Plant Microbe In 2006;19:699-710.

32. Silo-Suh LA, Stabb EV, Raffel SJ, Handelsman J. Target range of zwittermicin A, an aminopolyol antibiotic from Bacillus cereus. Curr. Microbiol. 1998;37(1):6-11. 
33. Moyne AL, Shalby R, Cleveland TE, Tuzun $\mathrm{S}$, Bacillomycin D. An iturin with antifungal activity against Aspergillus flavus. J. Appl. Microbiol. 2001;90:622-629.

34. He H, Silo-Suh LA, Handelsman J, Clard J. Zwittermicin A. An antifungal and plant protection agent from Bacillus cereus. Tetrahedron Lett. 1994;35:2499-2502.

35. Milner JL, Silo-Suh L, Lee JC, He H, Clardy J, Handelsman J. Production of kanosamine by Bacillus cereus UW85. Appl. Enviorn. Microbiol. 1996;62:30613065.

36. Hill DS, Stein JI, Torkewitz NR, Morse AM, Howell CR, Pachlatko JP, Becker JO, Ligon JM. Cloning of genes involved in the synthesis of pyrrolnitrin from Pseudomnas fluorescens and role of pyrrolnitrin synthesis in biologicalcontrol of plant disease. Appl. Environ. Microbiol. 1994; 60:78-85.

37. Thomashow LS, Weller DM. Role of phenazine antibiotic from Pseudomonas fluorescens in biological control of Gaeumannomyces graminis var. Tritici. J. Bacteriol. 1988;170:3499-3508.

38. De Souza JT, Arnould C, Deulvot C, Lemanceau P, Gianinazzi-Pearson V, Raaijmakers JM. Effect of 2,4diacetylphloroglucinolon Pythium: Cellular responses and variation in sensitivity among propagules and species. Phytopathol. 2003;93-97.

39. Chin-A-Woenget TF, Bloember GV, Lugtenber BJ. Phenazines and their role in biocontrol by Pseudomonas bacteria. New Phytol. 2003;157:503-523.

40. Hernandez ME, Kappler A, Newman DK. Phenazines and other redox-active antibiotics promote microbial mineral reduction. Appl. Environ. Microbiol. 2004; 70:921-928.

41. Haas D, Défago G. Biological control of soil-borne pathogens by Pseudomonads fluorescent. Nat. Rev. Microbiol. 2005;3: 307-319.

42. De La Fuente L, Quagliotto L, Bajsa N, Fabiano E, Altier N. Arias ainoculation with Pseudomonas fluorescens biocontrol strain does not affect the simbiosis between rhizobia and forage legume. Soil bio. and Biochem. 2002;34(4):545-48.

43. Lumsden Locke JC. Biological control of damping-off caused by Pythium ultimum and Rhizoctonia solani with Gliocladium virens in Soilless Mix R. D. Phytopathol. 1989;79:361-366.
44. Asaka O, Shoda M. Biocontrol of $R$. solan idamping off of tomato with $B$. subtilis RB14. Appl. Environ. Microbiol. 1996;11: 4081- 4085.

45. Pierson LS, pierson EA. Phenazine antibiotic production in Pseudomonas aureofaclens: Role in rhizosphere ecology and pathogen suppersion. FEMS Microbial. Let. 1996;136:101-108.

46. Howell CR, Stipanovic RD. Suppression of Pythium ultimum-induced damping-off of cotton seedlings by Pseudomonas fluorescens and its antibiotic, pyoluteorin. Phytopathology. 1980;70:712-715.

47. Kim BS, Lee JY, Hwang BK. In vivo control and in vitro antifungal activity ofrhamnolipid B, a glycolipid antibiotic, against Phytophthora capsici and Colletotrichum orbiculare. Pest Manage. Sci. 2000;56:1029-1035.

48. Howie WJ, Suslow TV. Role of antibiotic biosynthesis in the inhibition of Pythium ultimum in the cotton spermosphere and rhizosphere by Pseudomonas fluorescens. Mol. Plant- Microb. Interact. 1991;4:393399.

49. Jiao $Y$, Yoshihara T, Ishikuri S, Uchino $H$, Ichihara A. Structural identification of cepaciamide A, a novel fungitoxic compound from Pseudomonas cepacia D-202. Tetrahedron Lett. 1996;37:10391042.

50. Miller CM, Miller RV, Kenny DG, Redgrave $B$, Sears J, Condron MM, Teplow DB, Strobel GA. Ecomycins, unique antimycotics from Pseudomonas viridiflava. J. Appl. Microbiol. 1998;84:937944.

51. Hokeberg $M$, Wright SAI, Svensson $M$, Lundgren LN, Gerhardson B. Mutants of Pseudomonas chlororaphis defective in the production of an antifungal metabolite express reduced biocontrol activity. Abstract Proceedings ICPP98; Edinburgh, Scotland; 1998.

52. Thrane C, Nielsen TH, Nielsen MN, Olsson S, Sorensen J. Viscosinamide producing Pseudomonas fluorescens DR54 exerts biocontrol effect on Pythium ultimum in sugar beet rhizosphere. FEMS Microbiol. Ecol. 2000;33:139-146.

53. Baron SS, Rowe JJ. Antibiotic action of pyocyanin. Antimicrob Agents Chemother. 1981;20:814-820.

54. Slininger PJ, Behle RW, Jackson MA, Schisler DA. Discovery and development of biological agents to control crop pests. 
Neotropical Entomology. 32(2):183-95. Phenazines and their role in biocontrol by Pseudomonas bacteria. New Phytol. 2003; 157:503-523.

55. Dilantha WG, Nakkeeran S, Zhang Y. Biosynthesis of antibiotics by PGPR and its relation in biocontrol of plant diseases. Biocontrol and Biofertil. 2005;67-109.

56. Chernin L, Chet I. Microbial enzymes in biocontrol of plant pathogens and pests. In Burns R, Dick $r$ Editors. Enzymes in the Environment: Activity, Ecology, and publications. Netherlands, Marcel Dekker. 2002;171-225.

57. Liu X, Mohammed B, Yingxin M, Henry M, Ovadis M, Leo E, Berg B, Chernin L. Quorum-sensing signaling is required for production of the antibiotic pyrrolnitrin in a rhizospheric biocontrol strain of Serratia plymuthica. Microbiol. Lett. 2006;270:299305.

58. James Nairn D, Christopher Chanway P. Temporary loss of antibiotic resistaance by marked bacteria in the rhizosphere spruce seedling, FEMS Microbiol. Eco. 2002;40: 167-170.

59. Waters CM, Bassler BK. Quorum sensing: Cell-to-cell communication in bacteria. Annu. Rev. Cell. Dev. Biol. 2005;21:319346.

60. Raaijmakers JM, Vlami M, de Souza Jorge $T$ Antibiotic production by bacterial biocontrol agents. Antonie van Leeuwenhoek. 2002; 81:537-547.

61. Loh J, Pierson EA, Pierson LS III, Stacey $\mathrm{G}$, Chatterjee A. Quorum sensing in plantassociated bacteria. Curr. Opin. Plant. Biol. 2002;5:285-290.

62. Wei JR, Tsai YH, Horng YT, Soo PC, Hsieh SC, Hsueh PR, Horng JT, Williams $P$, Lai HC. A mobile quorum-sensing system in Serratia marcescens. J Bacteriol. 2006;188:1518-1525.

63. Eberl L, Molin S, Givskov M. Surface motility of Serratia liquefaciens MG1. J. Bacteriol. 1999;181:1703-1712.

64. Thomson NR, Crow MA, McGowan SJ, Cox A, Salmond GP. Biosynthesis of carbapenem antibiotic and prodigio sin pigment in Serratia is under quorum sensing control. Mol. Microbiol. 2000;36: 539-556.

65. Horng YT, Deng SC, Daykin M, Soo PC, Wei JR, Luh KT, Ho SW, Swift S, Lai HC, Williams $P$. The LuxR family protein SpnR functions as a negative regulator of $\mathrm{N}$ acylhomoserinelactone-dependent quorum sensing in Serratia marcescens. Mol. Microbiol. 2002;45:1655-1671.

66. Christensen AB, Riedel K, Eberl L, Flodgaard LR, Molin S, Gram L, Givskov M. Quorum-sensing-directed protein expression in Serratia proteamaculans B5a. Microbiol. 2003;149:471-483.

67. Rice SA, Koh KS, Queck SY, Labbate M, Lam KW, Kjelleberg S. Biofilm formation and sloughing in Serratia marcescens are controlled by quorum sensing and nutrient cues. J. Bacteriol. 2005;187:34773485.

68. Riley MA, Wertz JE. Bacteriocins: Evolution, ecology, and application. Annu Rev Microbiol. 2002;56:117-137.

69. Jack WR, Tagg JR, Ray B. Bacteriocins of Gram-positive bacteria. Microbiol. Rev. 1995;59:171-200.

70. Riley M. Molecular mechanisms of colicin evolution. Mol. Biol. Evol. 1993;10:138095.

71. Eijsink VGH, Axelsson L, Diep DB, Havarstein LS, Holo H, Nes IF. Production of class II bacteriocins by lactic acid bacteria; An example of biological warfare and communication. Antonie van Leeuwenhoek. 2002;81:639-654.

72. Chen H, Hoover DG. Bacteriocins and their food applications. Comp. Rev. Food Sci. Food Safety. 2003;2:82-100.

73. McAuliffe O, Ross RP, Hill C. Lantibiotics: Structure, biosynthesis and mode of action. FEMS Microbiol. Rev. 2001;25: 285-308.

74. Bai Y, Zhou X, Smith DL. Enhanced soybean plant growth resulting from coinoculation of Bacillus strains with Brady rhizobium japonicum. Crop Sci. 2003;43: 1774-1781.

75. Gray EJ, Lee K, Di Falco M, Souleimanov A, Zhou X, Smith DL. A novel bacteriocin, thuricin 17, produced by PGPR strain Bacillus thuringiensis NEB17: Isolation and classification. J. Appl. Microbiol. 2006; 100:545-554.

76. Ahern M, Verschueren S, Van Sinderen D. Isolation and characterization of a novel bacteriocin produced by Bacillus thuringiensis strain B439. FEMS Microbiol Lett. 2003;220:127-131.

77. Oscaris JC, Lasal Pisabarro AG. Detection and characterization of cerin 7 , a $n$ ew bacteriocins produced by Bacillus cereus with broad spectrum of activity. FEMS Microbial. Lett. 1999;178: 337-341. 
78. Kamoun F, Mejdoub H, Aouissaoui H, Reinbolt J, Hammami A, Jaoua $S$. Purification, amino acid sequence and characterization of Bacthuricin $\mathrm{F} 4$, a new bacteriocin produced by Bacillus thuringiensis. J. Appl. Microbiol. 2005;98: 881-888.

79. Cascales E, Buchanan SK, Duché D, Kleanthous C, Lloubès R, Postle K, Riley M, Slatin S, Cavard D. Colicin Biology. Micro. Mol. Bio. Rev. 2007;71:158-229.

80. Siddiqui ZA. PGPR: Biocontrol and biofertilization. Springer, Dordrecht (ed.), The Netherlands. 2005;12:67-109.

(C) 2017 Singh et al.; This is an Open Access article distributed under the terms of the Creative Commons Attribution License (http://creativecommons.org/licenses/by/4.0), which permits unrestricted use, distribution, and reproduction in any medium, provided the original work is properly cited.

Peer-review history:

The peer review history for this paper can be accessed here: http://sciencedomain.org/review-history/19475 